\title{
A MIDDLE ENGLISH TEXT ON PHLEBOTOMY
}

\author{
Francisco Alonso-Almeida \\ Universidad de Las Palmas de Gran Canaria
}

\begin{abstract}
This paper has a twofold objective. The first one is the edition of the text in Wellcome Library, MS5650, ff. 58v-61v, and the second one concerns the study of its language and its textual organisation. To my knowledge, this manuscript has not been edited before, and belongs to a volume of fifteenth-century medical items bound together. There is apparently no relationship among these items, and the only connecting thread is the practical nature of these texts. The analysis of the language will allow me to tentatively locate the text from a dialectal perspective. This detail along with the analysis of the physical features of the text will help me to provide a more exact date of production of MS5650, ff. 58v-61v. For a more comprehensive study of the text, its characterisation from a genre perspective is offered. The conclusions of this paper comprise all the partial findings, and in so doing a complete picture of MS5650, ff. 58v-61v as both a social and a linguistic object is presented.
\end{abstract}

Keywords: Edition, Middle English, Phlebotomy, Wellcome Library, Textual Criticism, Textual Genre.

UN TEXTO SOBRE FLEBOTOMÍA EN INGLÉS MEDIO

\section{RESUMEN}

Este artículo persigue un doble objetivo. El primer es la edición del texto en Wellcome Library, MS5650, ff. 58v-61v, y el segundo se refiere al estudio del estudio de su lengua y de su organización textual. Hasta donde es posible indagar, no hay información de que este manuscrito no haya sido editado. Pertenece a un volumen de textos médicos del siglo $\mathrm{xv}$, aparentemente, no hay relación entre los documentos del compendio, y su único hilo conductor es la naturaleza práctica de los textos. El análisis de los rasgos lingüísticos me permitirá ubicar el texto dialectalmente. Esto, junto con el análisis de las características físicas del texto, me permitiría proporcionar una fecha más exacta de producción del MS5650, ff. 58v-61v. Para un estudio más exhaustivo del texto, se ofrece una caracterización del mismo desde una perspectiva de género. Las conclusiones de este trabajo incluyen todos los resultados parciales y, al hacerlo, una imagen completa de MS5650, ff. 58v-61v, como objeto social y lingüístico.

Palabras clave: edición, Inglés Medio, flebotomía, Wellcome Library, crítica textual, género textual.

DOI: https://doi.org/10.25145/j.recaesin.2020.80.03

Revista Canaria de Estudios Ingleses, 80; April 2020, pp. 29-49; ISSN: e-2530-8335 


\section{INTRODUCTION}

Medieval medical texts have received uneven editorial attention in the last decades. While every effort has been done to produce seemingly extensive and representative compilations of these texts, the majority of which largely funded by public institutions, thorough critical editions of Old English and Middle English medical texts are still expected ${ }^{1}$. The idea of what is scientific today has motivated frantic waves of medieval textual compilations in order to meet the quantification rules in contemporary scientific methodology ruled by statistics, indicators, and probabilistic means. Depending on the interests of the compilers, some of these corpora contain lemmatizations, other include part-of-speech XML-tags, and very refined compilations present, say, additional information on visual aids in the manuscripts from which the texts have been excerpted. The direction taken in scholarly linguistic research is commendable and, of course, very much needed to comply with the rules of the game. This article pursues, however, a different goal, and an edition of a bloodletting text in the fashion of the work done back in the mid-twentieth century is intended. The product of this edition might be eventually of use for later inclusion in the mentioned larger textual databases, should the text meet the needs of the compilers and of the purposes of the compilation.

This article proposes an edition of the text in the Wellcome Library, MS5650, ff. $58^{v}-61^{v}$, along with information pertaining to its physical and language features. A glossary of Middle English words will be given after the edition for ease of reading. This said, the structure of this paper is, as follows. Section 2 offers an overview of phlebotomy in the Middle Ages, with an indication of earlier work performed on phlebotomy texts from this period. Later, in section 3, I focus on a description of Wellcome Library, MS5650, henceforward W, in codicological terms. In the following section, I offer information on the palaeographic, language and dialectal features of W. The last section is the edition of this item with textual apparatus, notes and a glossary of words excerpted from the edited text.

\section{PHLETOBOMY IN THE MIDDLE AGES}

Medieval medicine is both an art and a craft, and sufficient proof has come to us in the form of textual witnesses attesting for the interest medicine arouse among medieval scholars and layfolk (see Voigts). The education in medicine was extremely dear in the medieval period, and so was therapeutic assistance by learned professionals. This was among the reasons to find alternatives, less expensive means of therapeutic treatments. Evidence of this is found in the number of practical texts

1 Surprisingly, medieval recipe compendia have received much editorial attention in the last centuries and nowadays of different quality. For a careful edition of medieval receptaria, see Hunt and Benskin. An instance of an earlier edition is Ogden. 
based, as was pointed out in Alonso-Almeida and Carroll, as well as in de la Cruz Cabanillas, on academic texts. These texts circulated on demand and served an instructive function in those cases in which ordinary healers needed to perform some medical technical procedures. Thus, an English text on bloodletting like the one edited here represents a much lighter version of its phlebotomy master texts in either Latin, or in their translated forms in English or Norman French.

Phlebotomy by bloodletting has a long history coming down from earlier than the Egyptians (Davis 6). In the Middle Ages, this practice was also known and used, even if we cannot precise the popularity and frequency among practitioners. The truth is that countless medical texts contain directions on how to perform the procedure of bloodletting on humans, and where this should be done (see Voigts and $\mathrm{McVaugh}$ ). A good example is the homo venarum found in the Wellcome manuscript $8004, \mathrm{f}$. $18 \mathrm{r}$. This represents a beautiful decorated figure of a man surrounded by portions of text in either red or black ink indicating the place and names of veins in the body along with a short description, e.g. "The vayn in the vtturst part of pe nose opynd helpis pe brayne \& clense pe mynde" (my transcription). This information is very similar to the description of the therapeutic functions of bloodletting depending on the veins on which this operation is carried out in W, ff. $58 \mathrm{v}-81 \mathrm{v}$.

A technical aspect of bloodletting reports on the specific days in which this practice could be done, and almanacs often contain this information for availability to the surgeon or barber. They believed that there were good and bad days for bloodletting depending on the position of the moon and the planets (Stell 16). Parapia (491, after Dingwall 40) formulates this by drawing from historical evidence:

A manuscript dated 1595 'Ane Gude Boke of Medicines' states 'for letting of blude thair be thrie perrellous dayis in the year', and gives the following advice 'The last day of Apryll the first Monday of August and the last Monday of December. These thrie dayis be forbidden for they ben all ye waynes full of bode of every man. And yrfoir gif a women or man be latten blude on these dayis they sall dye wtin xv dayis'. There were, on the other hand, some auspicious days for, bloodletting. If the procedure was carried out on 18 April there would be no fever; on 3 April no headache; and on 17 December or September, St Lambert's day,' he shall not fall in no dropsie, fransy or tisyke'. ${ }^{2}$

In W, ff. $58 \mathrm{v}-61 \mathrm{v}$, astrological significance is disclosed in the reference to months of the year and festivity days rather than as exact reference to the moon, the stars and the planets in order to signal recommendation to practice or to avoid certain therapeutic procedures. Medieval books and quires on practical medicine contain numerous instances of how, where and when a person should undergo bloodletting in order to restore balance of their bodily fluids, and consequently of their good health conditions. This belief was perpetuated over centuries (Siraisi 97),

2 The months mentioned here coincide with those mentioned in W, f. $58 \mathrm{v}$, but the days mentioned in both are different, except for the month of December. 
evidence of which are the number of books mentioning and describing this excess of fluids and how to avoid this bodily disorder. Much of this knowledge recaps on the classical masters, as Hippocrates Galen and Socrates, who recommended the elimination of excessive humoral substance (Matheson 247). This information is echoed in medieval medical works, written either in Latin or in other vernaculars (cf. the pseudo-Bedan De Minutione Sanguinis, sive de Phlebotomia and Mirapice's work on bloodletting).

The practice of bloodletting could be innocuous to some extent, but it could also be life threatening, and that is the reason for some to disdain it, as is the case of the English Helmontians in the seventeenth century, in favour of a more rational and chemistry-based type of treatment (Taavitsainen et al. 19), as pointed out by Wear (383): "Blood-letting symbolised for Helmontians the intransigent hostility of Galenic medicine to any questioning of its methods and to any innovation". The advent of a more scientific type of medicine meant the abandonment of this practice, at least in the developed countries. W, ff. $58 \mathrm{v}-61 \mathrm{v}$, relies on contemporary circulating texts, which were based on the works of the classical writers and their witnesses, and still recommends bloodletting on certain days and on certain dietary conditions, as we shall see.

\section{W WELLCOME LIBRARY, MS5650}

London, Wellcome Libray, MS5650 is described under the heading 'Medical compendium in English' in the online catalogue of the digital collection of the Wellcome Library (London, UK). According to this online catalogue, MS5650 seems to be in a fragile condition. Torn edges and dirt on the first leaves suggest a later binding. The date of production is approximately the fifteenth century. This will be later supported using palaeographic and linguistic data.

The manuscript contains 120 folios and two vellum final flyleaves and this volume is bound in medieval wood boards covered by leather. Quires are sawn and put together by three double thongs attached to the margin of the boards. The book spine shows sewing method as it has not been covered with leather. There is no decoration on the covers, but there is evidence of a missing metal clasp to keep the book close. The volume is $220 \times 155 \mathrm{~mm}$. According to the catalogue details, folios 1, 8-9, 16, 22-23 are vellum. Collation is also provided in the catalogue, and reads, as follows (this collation uses pages rather than folios): 1 16, 216 wanting 1-2, 15-16 (15-16 probably blank), $312,412,512$ wanting 10-12 probably blank, 610 wanting 7-10 probably blank, 714 wanting 9-14 probably blank, $816,94,10$ 15, 11 10. Quires missing between 8 and 9 and 10 and 11 .

Visual inspection of the digitised manuscript reveals that $\mathrm{f} .7$ is severely damaged to the extent that more than two thirds of the folio have been torn away. Despite the description of quire 2 as wanting folios 2, 15 and 16, my examination of the book and the text on those folios reveals that these folios are present in the volume. The text follows nicely from one folio to the next. The excessive dirt on f. $16^{\mathrm{v}}$ indicates that this quire was loose for a good while until bound as part of 
the volume. Quire 3 had originally 8 folios, wanting 1-2, 3-4. Quire 4 also had 8 folios, wanting now 13-14, 15-16. From quire 5 onwards, there is no contemporary foliation starting ' 2 ' until folio 97 in present day script.

W is written by different scribes in English and Latin. The catalogue informs that the volume was compiled in the Westmoreland area. There are also additions by later hands. The practical nature of W is evinced in the items collected, among which there are medical and culinary recipes along with a treatise of the diseases of women, with some others. The exact contents taken accurately from the catalogue are the following:

\begin{tabular}{|c|c|}
\hline Item & Contents \\
\hline ff. $1 \mathrm{r}-28 \mathrm{v}$ The 'Boke of maschalse' & $\begin{array}{l}\text { Incipit: 'The boke of marschalse here it schall begyn...Iff } \\
\text { pat pou hafe stede folse to kepe...' } \\
\text { Explicit: 'Explicit per dominum Johannem Marshall } \\
\text { vicarium sancti Michell de Appelby' }\end{array}$ \\
\hline ff. $29 \mathrm{r}-40 \mathrm{v}$ Herbal & Incipit: 'Ruw is hot and dry and dos goode to pe stomak...' \\
\hline ff. $41 \mathrm{r}-58 \mathrm{r}$ Treatise on the sicknesses of women & $\begin{array}{l}\text { Incipit: 'Here begynnys the sekenes off women whylk is } \\
\text { callyd the moder. Also we salt understande pat women has } \\
\text { lesse hete in pe body pan men...' }\end{array}$ \\
\hline ff. 58v-61v Phlebotomy treatise & $\begin{array}{l}\text { Incipit: 'Ffor blode lettynge. Seth pe authoritie of ypocras } \\
\text { pe noble phisiciane...The vayne in pe myddest of the for } \\
\text { hede serves for hede ache and for pe mygrayn...' }\end{array}$ \\
\hline \multicolumn{2}{|l|}{$\begin{array}{l}\text { ff. } 62 \mathrm{r}-67 \mathrm{v} \text { Trotula, Tractatus de egritudinibus } \\
\text { mulierum }\end{array}$} \\
\hline $\begin{array}{l}\text { ff. } 68 \mathrm{r}-75 \mathrm{v} \text { Collection of culinary recipes for } \\
\text { meat, fish and vegetable dishes }\end{array}$ & $\begin{array}{l}\text { Incipit: 'Hic incipit modus iusquendi qualiter cocus se } \\
\text { habebit in coquinis circa cibaria diversa preparanda. } \\
\text { Swan. To slee all maner of birdes to roste pame and to } \\
\text { sause pame...' }\end{array}$ \\
\hline $\begin{array}{l}\text { ff. } 76 \mathrm{r}-88 \mathrm{v} \text { Recipes for drinks, salves, unguents, } \\
\text { etc. }\end{array}$ & $\begin{array}{l}\text { Incipit: 'Here may thou lere diverse manner off makyng } \\
\text { of salves, drynkes, siropes, plasters, oyntementes, and } \\
\text { gude entretes... }\end{array}$ \\
\hline ff. $89 \mathrm{r}-91 \mathrm{v}$ Tract on making aqua vitae & $\begin{array}{l}\text { Incipit: 'Aqua vite and pe makyng peroff. Take camphore... } \\
\text { in distillatorio cum vino ponantur et ad lentum ignem } \\
\text { distilles.' }\end{array}$ \\
\hline f. $91 \mathrm{v}$ On the making of oils & $\begin{array}{l}\text { Incipit: 'Her beginnys pe makyng off oylys. Oleum masticis } \\
\text {... The end of the work is wanting. }\end{array}$ \\
\hline \multicolumn{2}{|l|}{$\begin{array}{l}\text { ff. } 92 \mathrm{r}-95 \mathrm{v} \text { Treatise on uroscopy. } \\
\text { The beginning and end of the work are wanting }\end{array}$} \\
\hline ff. 96r-120v Recipe collection & $\begin{array}{l}\text { Incipit: 'Ictericia. Item ad [?] mundificare cutem cum } \\
\text { aceto albo tepido et decoctione capille veneris eupatorii } \\
\text { et ordei ... }\end{array}$ \\
\hline
\end{tabular}

Catchwords in W include f. 11r 'ye hors they', f. 13r 'whyle', f. 16v 'yat fynger', f. $24 \mathrm{r}$ 'surs of rye', f. $52 \mathrm{v}$ ' $m a k e$ ye modyr to drawyn hyr vpp in water', f. 86r 'erthe', f. $88 \mathrm{v}$ 'pan', f. 91v 'Oyle of swete almond', f. $115 \mathrm{v}$ ' $\&$ ye hete', f. $120 \mathrm{r}$ 'res'. These catchwords are accurate. The folios mentioned correspond to modern foliation, as some medieval folios are missing from the original. 
The support of W is paper, but parchment has been used on folios 1, 8-9, 16, 22-23. There are some folios on which lines have been scored for designing the writing space. These lines have been done by pressing some point of lead to mark the paper without using ink. Others do not present these lines. No traces of pricking have been detected. The text is written in a single column throughout with some marginal additions in contemporary and later hands.

Ordinatio in running text is supported by specific headings preceding some items, and the use of red ink and red underlining in the case of the recipe compendium. The use of red paraph marks also serve this same function. $\mathrm{W}$ is certainly not rich in the use of decoration. There is one initial capital letter $\langle\mathrm{H}\rangle$ with only a right shank, being the second missing in the form of a large minuscule $<\mathrm{h}>$. This letter occupies approximately five lines, and it has been designed in brown with shades of red and a curly spine to finish at the top. Hanging red initials are used in the two tracts on the diseases of women. In the case of the Tractatus de egritudinibus mulierum, initials appear only from folio $64 \mathrm{r}$ up to $67 \mathrm{v}$. A hanging initial is also found on $\mathrm{f}$. $1 \mathrm{r}$ at the start of the 'Boke of Maschalse'. In the case of our text, there is a manicule in a later hand used as a signalling device to indicate the suitable time for bloodletting on f. 59v. Another marginal note is 'no' on f. $58 \mathrm{v}$ to indicate unfavourable days for bloodletting.

As to early provenance and ownership, following the information on the catalogue, there are the fifteenth- to seventeenth-century signatures of Lancelot Denton on f. 22r, Georgius Harrison, Thomas Gent and Mary Williamson ff. 22v23r, Recardus Hygins f. 23v, Edward Johnstone f. 96r-v. On flyleaves, information from a rental for Appleby and the surrounding area. The volume was acquired from Christie's (3 Dec. 1986, lot 349) and purchased from Dr David Segal in 1989, as noted in the online catalogue.

\section{W, ff. $58 v^{-6} 61 v$}

The text edited here from $\mathrm{W}$ is an instance of a medieval medical practical knowledge being taken from learned sources dealing with medical matters. As I shall show in due course, this text seems to be a digested version of a technical text in which jargon has been reduced to a very minimum, so that a non-trained practitioner may be able to understand the information given. I have consulted several databases and catalogues of manuscripts in order to ineffectively identify any other extant version of this text.

W, ff. $58 \mathrm{v}-61 \mathrm{v}$, is the work of a single scribe under the contemporary heading 'For blode lattyng'. The text is written using a cursive hand mixing letters from the anglicana formata and the secretary scripts in a sort of brownish ink; in some portions of text the ink is clearly fading away. The style in our manuscript item shows looped descenders, as in the case of the letter $<y, h, j, x>$ and the ampersand $\langle \&>$, for example. Instances of looped ascenders include some cases of the letters $<\mathrm{s}>$ and $\langle\mathrm{f}>$, the letters $<\mathrm{k}, \mathrm{l}, \mathrm{h}>$ and some abbreviations. Letter $<\mathrm{a}>$ reflects the characteristic Anglicana double-compartment. Letter $<$ g $>$ also reflects the typical 
Anglicana 8 -shape. There are the 6 -shape letter $\langle\mathrm{s}\rangle$ and the tall $<\mathrm{s}\rangle$. The forms the letter $<\mathrm{r}>$ shows in the manuscript are the short type and the long descender type. There is also the round $<\mathrm{r}>$, as used in the word thorow, for instance.

The contents of this item include the unfavourable days for bloodletting and when in the day bloodletting is recommended (1l. 1-12); the bloodletting veins, location of veins and their therapeutic associated benefits (1l. 13-187); and the virtues of bloodletting (ll. 188-191). As indicated in the notes, reference is made to Hippocrates through Isidore of Seville's writing (1l. 2-3), probably from the appended item to Isidore's Etymologies, i.e. De initio medicinae (Codoñer 18). A closer reading of the text reveals that the Etymologies, including its appended item, does not seem to be the main source for W, ff. $58 \mathrm{v}-61 \mathrm{v}$.

There is, however, evidence that the source of our edited text might be the pseudo-Bedan De minutione sanguinis sive de phlebotomia. Even if our Middle English text is not evidently an accurate witness of the De minutione, information on the favourable and the unfavourable days for practising bloodletting might have been taken from this text, as shown in the following excerpts, which additionally shows the influence of astrology on surgical procedures:

Plures sunt dies Ægyptiaci, in quibus nullo modo nec per ullam necessitatem licet homini vel pecori sanguinem minuere, nec potionem impendere, sed ex his tribus maxime observandi, octavo Idus April. illo die lunis, intrante Augusto: illo die lunis, exeunte Decembri: illo die lunis, cum multa diligentia observandum est, quia omnes venæ tunc plenæ sunt (De minutione in Giles 350).

De ambis temporibus incidimus, propter effusionem oculorum. De subtus lingua, duas propter rheuma gingivarum, vel vitia oris, et dentium dolorem ( $D e$ minutione in Giles 350).
Seth ye autorite of Ypocras, ye noble phisiciane Ysoder tellis yat yer be thre days in ye zere jn ye whilk dayes a man ne sall noght be lett blode. And these bene ye dayes: the 8 kalender of April, the forth day of August, the laste day of Decembre (W, f. 58v).

The two vaynes vnder ye tonge serues for swetyng $\&$ fluxes \& totheache $\&$ gommes and rewmes of the hede $\&$ appostems and squisies of the throte $\&$ for swonnynges \& sikkynges \& ye cowth \& for ye wikkyd euele $\&$ for all vices of the mouthe (W, f.59r)

W, ff. $58 \mathrm{v}-61 \mathrm{v}$, is written in English throughout, and to my knowledge, dialectal provenance has not been yet confirmed, and W has not been considered for localisation in the LALME, either. Evidence based on this manuscript indicates a northern stratum, especially Westmorland in Cumbria.

As to language use, nouns in this text do not present traces of Old English inflections, except for marking the plural and the genitive form. The inflectional endings for the plural are $-s$ and $-n$ (numbers in brackets refer to lines in the edition), as in vaynes (8) and eene (24), respectively. These two inflectional ways of forming the plural may be used for the same word at the same time: bones and bonen (66), armes (10) and armen (80), vaynes (8) and vaynen (123). The genitive is also marked with $-s$, as in a womans flowres (152), ballokkes stones (126), although zero marking is also possible, as in ballok stones (163). Mutated plurals as the result of an earlier i-umlaut have been also identified, as in fete (12)/ feete (151) and men (132).

Adjectival distinctions concerning gender, case and number are not retained in this text (cf. Horobin and Smith 106). Adjectives appear to be invariable, and 
there is no trace of the $\mathrm{OE}$ strong/weak distinction on these forms: vnclene (8), gude (19), strayte (82), lytyll (115), cold (173), right (173). Degree is expressed in this text by means of synthetic devices: -er for the comparative, as in lawer (129) and -mare (122), and -st for the superlative, as in myddest (13). There is also the use of best (111) and next (41) as a case of irregular superlative. As to adverbs, these are formed by the addition of the suffix -ly, onely (9), specially (68), and namelyche (92); the last one still reflecting the $\mathrm{OE}$ adjectival suffix $-l i c$, also used with final $-e$ to form the adverbial form.

Pronouns in the text include: (a) personal: $3 \mathrm{~s}$, neuter: $j t(7), i t(19)$, gen. masc.: his/ys (110); 3s obj. masc. hym (171); 3pl.: yai (78); gen.: yair (158); obj.: yane (158); (b) indefinite: one (71), other (69); (c) partitive: ylkan (34); (d) demonstrative: these (5).

Articles are ye (2)/ the (25), and ane before words with vowels initially, as in ane euyle (14).

Verbs in the infinitive have generally no specific endings, although forms may carry final $-e$ and one case of $-e n$ as the result of inflectional levelling from Old English - an ending for the infinitive. These forms may cooccur with (for) to: for to wete (7), for to clens (27), to blede (64), and for to staunchen (151). The verbs for the present tense indicative show inflectional endings for the indicative third person singular and plural. Forms include $3 s-i s,-y s$ and $-e s$, as in hauntis (92), tellis (3), seruys (55), serues (71), and 3pl. - yn, as in clepyn (133). These forms suggest, as already pointed out, a northern stratum for W, ff. 58v-61v. Present subjunctive apparently carries no additional person marking, and its form is alike the indicative simple past. There is the only instance of 3 s swone. The imperative is like the infinitive with or without the ending -en: wessch (168) and bathen (176).

The passive is made up of the verb to be in the infinitive or in its obliques; the past participle endings are weak $-e d,-i d$, and $-t$; and strong $-n$ : is called (18), $i$ clepyd (84), be latt (133), be lattyn (10). The verb to be is: subjunctive be (170); 3 $s$ prs. ind. $y s$, is; 3 pl. prs. ind. bene, or. Preterite-present verbs in this text are moie 's. may sg.' (167), may 'may pl.' (157), mete 'might' (78), mot 'must' (38), most 'must' (68), sall 'shall' (134), shall (169), shuld 'should' (10). These forms have been attested in areas of the North, except for the variant mete 'might' that is not registered in the $L A L M E$. The forms shall and shuld are not very common in the North from which this text seems to be. The variant shall in this area is very distinctive occurring only in five LPs. One of which corresponds to the dialectal area of Westmorland.

This state of the language roughly confirms the catalogue date for this manuscript entry, i.e. the $15^{\text {th }}$ century, although, particularly, in the case of the item edited here, an approximate date should be some point in the late $14^{\text {th }}$ century. This is also supported by the dialectal localisation of this text which shows some degree of standardisation although a number of colourful forms still persist.

The linguistic profile (LP) given below has been designed following the directions in the $L A L M E$ and localisation has been performed focusing on the information in this LP and on the morphological evidence described earlier. Sporadic forms are given within triple brackets. 


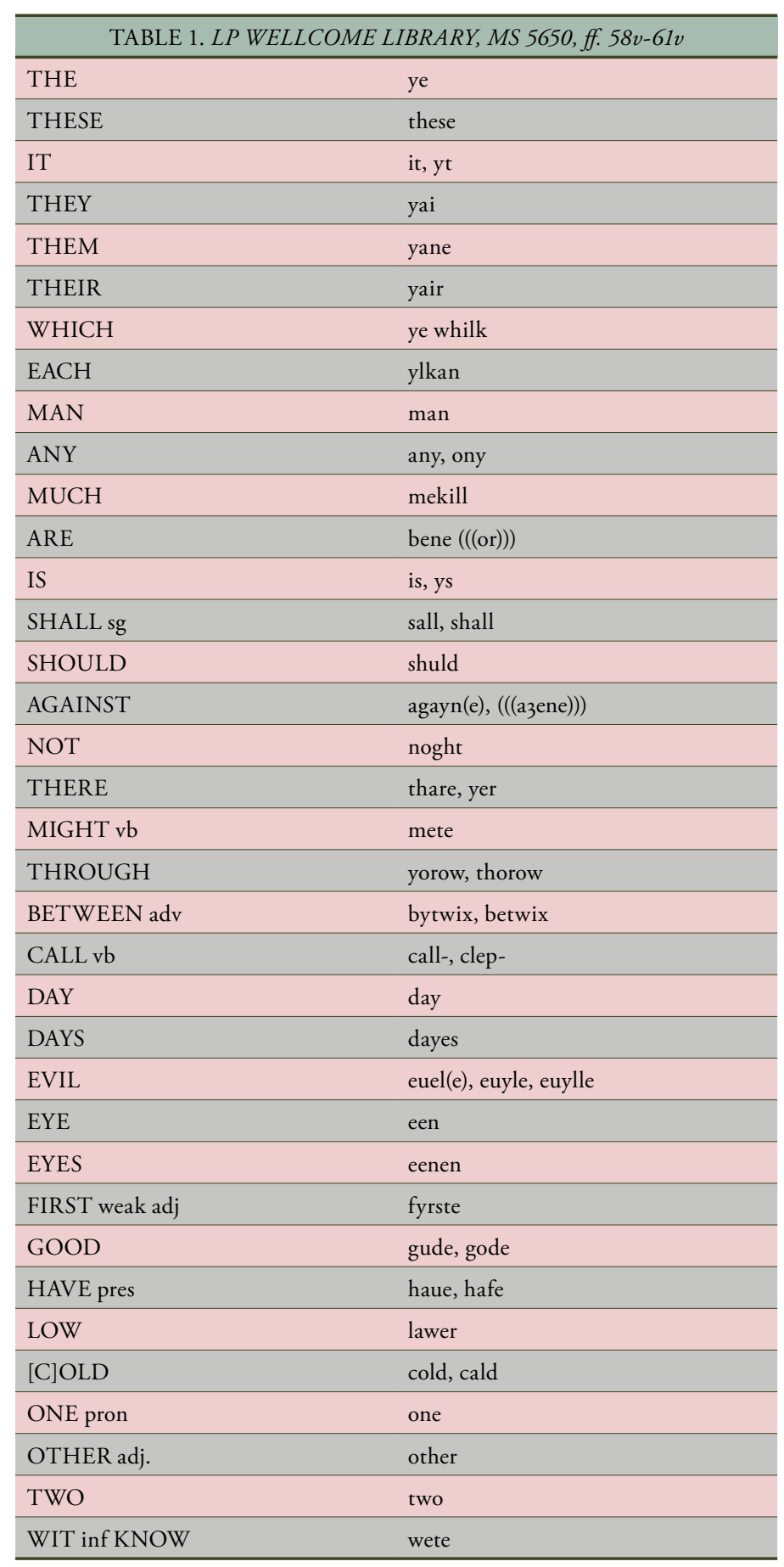


Dialectal localisation of the text has been carried out focusing on the LP in Table 1, as already said, and also on the dot maps in the LALME. The LP shows some distinctive Northern features. The forms for bene and or are found in this area. In the case of the former, it is attested in the dialectal regions of Yorkshire and Westmorland. As to the latter, this form does not appear in the LALME. The form SHALL: sall is quite spread in the North, and SHALL: shall is more exclusive in this area and is registered in the LALME in Westmorland and Northumberland. The form shuld is recorded in specimens from Durham, the Isle of Man and Westmorland. Another defining feature is agayn 'against'. This form is not widespread in the North and appears in Westmorland and Yorkshire. The form azene is not a northern feature, and it has been attested in the county of Norfolk in the LALME, and this might suggest that this form is a variant as the result of copying from an exemplar or a variant as the result of the scribe's own idiolect (cf. Benskin and Laing).

The localisation of the word thare 'there' has been found in the areas of Durham, Lancashire, Westmorland, York, and Lincolnshire. The form betwix 'between' in its current manuscript form in two words is extensively used in Westmorland and neighbouring areas. The forms gude and gode for the item GOOD have been registered for several counties of the North, including York, Lincolnshire, and Durham, among others, and the region of Westmorland, where both gude and gode coexist. The same happens with the variants hafe and haue, being the second of these far more popular than hafe in areas of the North, although both forms have been attested in documents of the Westmorland area.

The word lawer for the item LOW is localised in some areas of the northeast of England to Cumberland, Westmorland and Lancashire. The distinction $<$ a/ os preceding the homorganic consonant cluster <-ld > keeps both variants in the text edited here, hence cold, cald (see Jordan-Crook 92 for the cald variant). The form with $a$ is basically found in areas of the North. In the text, another form with $a$ from its ancestor Old English long sound /a:/ is identified, i.e. -mare in the word ouermare (122-123). All these features confirm the Northern stratum of W, ff. 58v$61 \mathrm{v}$, specifically the region of Westmorland, as suggested by the number of variants in the edited text localised in this area. A comparison of the LP designed here with LP 389 in the LALME is clarifying. Actually, this LP 389 also includes evidence of fortition of the voiceless interdental fricative represented in spelling by $<-$ th $>$ in numerals into voiced or voiceless plosive sounds represented in spelling by $<-t>$ or $<-\mathrm{d}>$. In W, the form seuened 'seventh' suggests the same process of fortition.

The lexicon of W, ff. 58v-61v, reflects the type of words that are representative of this type of medical technical texts, even if, as already pointed out, jargon has been kept to a minimum in order not to hinder understanding to the non-professionals. The vocabulary used in this text suggests different traditions. This encompasses the names of sicknesses, plant names, medical products and implements. These lexical items display a high influence of Latin (or Greek via Latin) and French. Some examples taken from the text may illustrate the influence received from these languages (information has been drawn from the Oxford English Dictionary and the Middle English Dictionary): colica passio < ML colica passio; mygrayn < OF migrai(g) ne $(<\mathrm{L}$ hemicrania $<\mathrm{Gr}$ hemikrania); apostemes $<\mathrm{OF}$ aposteme, apostume, empostume 
and ML apostema; jaundes < OF jaunice, gaunisse and AN jauniz; feuers < OE fefer $<\mathrm{L}$ febris; kancer < OE cancer < L cancer; < medieval squisies < Latin squinancia, -antia, apparently formed by confusion of Greek $\sigma v \nu \alpha \dot{\gamma} \gamma \eta$ and $\chi v \nu \alpha \dot{\gamma} \chi \eta$; venegre $<$ $\mathrm{OF}$ vinaigre, vinagre and $\mathrm{AN}$ vinegre, vinegar; and spices < $\mathrm{OF}$ espece, espi(e)ce, espis(c) $e$ and AN spece from L species.

\section{EDITION}

A set of editorial principles has been followed in the edition of W, ff. $58 \mathrm{v}$ 61v. The scribe's own spelling conventions have been fully respected throughout this edition, including cases of variation to avoid concealing dialectal information. Variation in the use of $\langle\mathrm{u}>$ and $\langle\mathrm{v}>$ to indicate either a vowel or a consonant quality has been retained. The vowel sound represented by the letter $<i>$ in the PDE word list can be either $<\mathrm{i}, \mathrm{j}\rangle$ or $\langle\mathrm{y}\rangle$. These are also shown in the edition.

Abbreviations are expanded in conformity with the rest of the manuscript's spelling, and these are indicated using italics for reasons of their dialectal significance. Otiose marks in script have been excluded from the transcription, but abbreviation marks have been identified with reference to similarly spelled-out words used in the recipe book. These abbreviations are curly strokes to indicate the omission of a final -er, a sort of upturned $<a>$ to signal $-e s /-y s$, and tildes that indicate a missing nasal sound as in the word man. The ampersand symbol $\langle \&>$ has also been retained in the edition. Supralinear letters, normally $<\mathrm{t}>$ and $<\mathrm{e}>$, are also shown.

The scribe quite often uses word boundaries, which are meaningless in PDE. In this edition, I have amended those misdivisions, as I have not clear evidence that division has been purposefully intended by the scribe in all the cases. These words are a for, a boute, a bove, a gayne, a zene, be hynd, be twix, blodelattyng, hede ache, with in, and with oute.

As to punctuation in the original, the scribe of W, ff. $58 \mathrm{v}-61 \mathrm{v}$, uses several times the punctus, the virgula suspensiva, and the hyphen to establish periodic division within the text. These marks indicate the structure of the text, as well as the reading pauses. Paraph marks are deployed as marginal notes to signal therapeutic directions related to bloodletting.

Punctuation in the edition is editorial. Some uses of the punctus reflect PDE use of the point. The same applies to the simple and double virgule, and a PDE point has replaced this punctuation mark. Occasionally, the virgule and the punctus combine to indicate a same kind of segmentation. In these cases, a PDE point is also used. Other times either the punctus or the virgule may appear after an adverbial phrase, in sequences of any type of phrases, and before the word and (in phrases and clauses). All these instances of the punctus or of the virgule are a PDE comma or nothing in the edition. The punctus surrounding numerals have been removed from the transcription. The genitive is left as it stands in its manuscript presentation, without apostrophe, e.g. mans mynde rather than man's mynde (f. 60v).

The paraph marks in the margins have been retained as these are considered contemporary visual aids. There is one case of a triple virgule in the original to 
separate off two simple sentences. This mark is a point in the edition. An editorial colon has also been added. Capitalisation follows PDE conventions, and $<\mathrm{ff}>$ in initial position has been reduced to minuscule single $\langle\mathrm{f}\rangle$, except in the case of the word ffeuerzer, which is capitalised, thus Feuerzer.

The folio numbers are included in the edited text, and each line corresponds to a line in the manuscript. Lines are editorial and are given in the margin as a reference aid to follow the description of the text given earlier in this paper.

$58^{v}$ For blode lattyng.

S eth ye autorite of Ypocras, $y^{\mathrm{e}}$ noble phisi-

$\mathcal{S}$ ciane Ysoder tellis yat yer be thre dayes

in ye zere jn ye whilk dayes a man ne sall

noght be lett blode. And these bene $y^{\mathrm{e}}$ dayes:

the 8 kalender of April, the forth day of August, the

laste day of Decembre. Jt is for to wete

yat all the vaynes of ye hede yai bene vnclene after

mete, saue onely ye vayne vnder ye chyn.

Also ye vaynes of the armes shuld be lattyn

blode afor mete. And ye vaynes of ye handes $\&$ of

$y^{e}$ fete after mete.

The vayne in $y^{\mathrm{e}}$ myddest of the forhede serues for hedeache $\&$ for $y^{e}$ mygrayn yat is ane euyle $\mathrm{y} a^{\mathrm{t}}$ takes halfe $\mathrm{y}^{\mathrm{e}}$ hede $\&$ makes it to ake.

And also for the litarge y $a^{t}$ is ane euylle $y a^{t}$ makes

a man to forgete al yat he heres and y $a^{\mathrm{t}}$ commes yorow a

postym yat is called litarge. And it waxis behynd

no ye hede. And it is gude for $y^{\mathrm{e}}$ fransye \&

wodenes, and for $\mathrm{y}^{\mathrm{e}}$ brayne yat is defouled,

and for newe meselry.

The two vaynes in $y^{e}$ temples a $[t]$ both partes of the hede serues for akyng of the dece eres and for mekill waterynge of $y^{e}$ eene and agayne grete hete of the temples.

The two vaynes behynde $y^{e}$ eres serues for to make a man haue gude mynde $\&$ for to clens $y^{\mathrm{e}}$ face $\&$ for ye spottes in $y^{e}$ face $\&$ for rewms $\&$ filthes of the teth $\& y^{e}$ gomes $\&$ for all vices of $y^{e}$ mouthe.

2 Seth] There is an indication for the later addition of a hanging initial, i.e. $<$ s $>$ given in minuscule in contemporary hand, same script and ink. This initial has been, therefore, added in this edition.

$\overline{\mathbf{1 5 8 v}] 2 \text { Seth] }}$ eth $\mathbf{2 3}$ dece] $\wedge$ dece 
59r The two vaynes in $y^{\mathrm{e}}$ eres within serues for tremelyng of the hede $\&$ stoppyng of the hede $\&$ for tyngelyng of $\mathrm{y}^{\mathrm{e}}$ eres $\&$ for newe defenes. The two vaynes in $y^{\mathrm{e}}$ nekk ylkan of yane serues for all swellynges \& superflewites of $\mathrm{y}^{\mathrm{e}}$ cheuwynges teth \& gomes $\&$ chekes and for boches $\&$ appostymes of the throte withjn $\&$ withoute $\&$ yat blodelattyng mot be done with grete sotelte.

The two vaynes in $y^{\mathrm{e}}$ two cornes of $\mathrm{y}^{\mathrm{e}}$ eres next $y^{\mathrm{e}}$ nose serues for derkenes of $\mathrm{y}^{\mathrm{e}}$ een $\&$ for webbes $\&$ clowdes $\&$ pynnes of $y^{\mathrm{e}}$ een $\&$ for all fluxes $\&$ greuans of ye eene.

The vayne of $y^{\mathrm{e}}$ topp of $\mathrm{y}^{\mathrm{e}}$ nose serues for hedeache $\&$ for $y^{e}$ flux of ye eene $\&$ of the heuede.

The two vaynes $y a^{t}$ bene in ye jowes of the mouth serues for schewes of $\mathrm{y}^{\mathrm{e}}$ face $\&$ for schabes $\&$ schab of ye heued.

The two vaynes vnder $y^{e}$ tonge serues for swetyng \& fluxes \& totheache $\&$ gommes and rewmes of the hede $\&$ appostems and squisies of the throte $\&$ for swonnynges $\&$ sikkynges $\&$ ye cowth $\&$ for ye wikkyd euele $\&$ for all vices of the mouthe.

The vayne in ye hole of the nekk seruys for hedeache for wodenes \& fleble mynde and fluxes $\&$ rewmes of the brayn $\&$ of ye forhede $\&$ for all the hede.

$59^{v}$ The vayn vnder $y^{\mathrm{e}}$ chyn serues for swellyng $\&$ akynge of $y^{\mathrm{e}}$ iowes $\&$ of $\mathrm{y}^{\mathrm{e}}$ pappes $\& \mathrm{y}^{\mathrm{e}}$ breste $\&$ for rottyng $\&$ stynkynges of $\mathrm{y}^{\mathrm{e}}$ nosethrylles $\&$ boche in nosethrelles.

The hede vayne of both $\mathrm{y}^{\mathrm{e}}$ armes ache of yane is gode to blede for hedeache $\&$ for destres of ye hede $\&$ for greuans of the shulder bones \& akyng of ye rig bonen \& foulfallynges $\&$ swellynges \& fluxes of $y^{\mathrm{e}}$ een $\&$ wiky deuel ane yis bledyng most be specially befor all other tymes of ye yeer vppon ye seuened day of ye moneth of May.

63 ache] akache 
The two medil vaynes of ayther arme one serues for alle sorwes $\&$ defautes greuance $\&$ passions $\&$ cardiacles of ye hart $\&$ for ye brest $\& y^{\mathrm{e}}$ stomak $\& y^{\mathrm{e}}$ ribbes $\&$ ye sydes $\&$ for all ye membres with in ye body $\&$ for all vices of ye lunges $\&$ stoppyng yat makes a man haue strayt breth \& stynkyng, \& specially yai mete blede $y^{\mathrm{e}}$ fifte day of Septembre.

The two vayns in ye sercle of ye elbowes on ayther armen one serues for akyng of $\mathrm{y}^{\mathrm{e}}$ brest $\&$ for ye lunge $\&$ for $y^{\mathrm{e}}$ mydrife $\&$ for

strayte breth $\&$ for ye tisik \& for $y^{e}$ crampe $\&$ for akynge of $\mathrm{y}^{\mathrm{e}}$ worme yat is clepyd colica passio.

f. $60^{\mathrm{r}}$ The vayne bytwix $y^{\mathrm{e}}$ lityll fynger $\&$ ye leche $y a^{t}$ is next on ayther hande serues for swellynges of $\mathrm{y}^{\mathrm{e}}$ stones $\&$ of $\mathrm{y}^{\mathrm{e}}$ brest \& for wlatynges $\&$ for $\mathrm{y}^{\mathrm{e}}$ jaundes $\&$ for all vices of $\mathrm{y}^{\mathrm{e}}$ mylte yat commes thorow feuers or any other causes

The vayne betwix $y^{\mathrm{e}}$ thome $\& \mathrm{y}^{\mathrm{e}}$ next fynger

on ayther hande serues for hedeache yat hauntis a man, \& namelyche ye vaynes of the thome. Ye fyrste vennes or gude for all feuers, \& namely for $y^{\mathrm{e}}$ quarten, for schedyng of ye gall, \& for wikkyd brynnyng, \& for a rede nose, $\&$ for flux of teres in ye eenen.

The vayne withjn $y^{\mathrm{e}}$ thees next $\mathrm{y}^{\mathrm{e}}$ shear serues for all vices of ye emeraudes $\&$ for $y^{\mathrm{e}}$ flux $\&$ ye blodymenyson $\&$ for ye chaudpysse $\&$ for ye ^blodder.

The vayne in $y^{\mathrm{e}}$ rigg bone ende serues for all $\mathrm{y}^{\mathrm{e}}$ greuans of rig bone $\&$ of $\mathrm{y}^{\mathrm{e}} \mathrm{bak} /$

The two lyuer vaynes on ayther arme one serues for tremellynges schrynkynges of synowes in $\mathrm{y}^{\mathrm{e}}$ armes $\&$ handes \& fyngers \& azene all feblyng rotyng $\&$ defaute of ye lyuer of ye lunges \& ye brest $\&$ y ${ }^{\mathrm{e}}$ mylk \& ouer mekill waxing of ye gall $\&$ for akyng of ye bakk $\&$ ye shulder bones \& ye ribbes $\&$ ye sides $\&$ all ye membres within $\&$ for bledyng at ys nose $\&$ for all feueres. The best day of $\mathrm{y}^{\mathrm{e}}$ yere is ye seueneth day of May.

f. $60^{v}$ The two vaynes on ayther side one of ye body bene clepyd craluestelle $\&$ yan bene 
aboute ye lytyll fynger and serues for $\mathrm{y}^{\mathrm{e}}$ han-

ches $\&$ for ye eene $n \&$ for ye face $\&$ for other partes of ye body.

The two vaynes in ye thees with in on ayther hempp serues for akynges of ye reynes $\&$ y bleddes

$\&$ for all maner of gowtes $\&$ dropsies and shrynkynges \& swellynges of all ye body. Thare bene two vaynes on ye pyntell ye ouermare vaynen serues for $y^{\mathrm{e}}$ crampe $\&$ for ye euel $\mathrm{y} a^{\mathrm{t}}$ is callyd Collica Passio $\mathrm{y} a^{\mathrm{t}}$ is a swellyng in ye wombe $\&$ wynde horlynges $\&$ for all maner swellynges of ballokkes stones $\&$ for ye wombe $\&$ for ye stonen euele $\&$ for ye bledder $\&$ for ye reynes.

The vayne lawer on $y^{e}$ pyntell next $y^{\mathrm{e}}$ huske is gude for $\mathrm{y}^{\mathrm{e}} \mathrm{dropcy} \&$ all his spices.

.9. Thare bene two vaynes thre fyngers mele above ye knees on ayther kne, one yat men clepyn "sagittes". If yai be latt blode, ye man sall dye on one sodenly with leyhzning. Bewar of yat.

The two vaynes vnder $\mathrm{y}^{\mathrm{e}}$ knees in both $\mathrm{y}^{\mathrm{e}}$ legges yat is in ye harmmes, yai serue for all passions $\&$ ye defaute of ye reynes $\&$ ye bledere $\&$ for f. $61^{\mathrm{r}}$ ye longes $\&$ entrayles agayne boches and postemes \& swellynges $\&$ rotynges of the thees $\&$ legges, \& specially agayn ye goute in the heppes \& ye legges handes \& fete.

The two veynes on $y^{e}$ lytyll too ayther fote one serues for ye reynes $\& y^{\mathrm{e}}$ bledder $\&$ for the gendrynges membres $\&$ for ye palsie $\&$ for all euele goutes.

The two vaynes vppon $\mathrm{y}^{\mathrm{e}}$ grete too on ayther fote one serues for whebbes $\&$ spottes in $y^{\mathrm{e}}$ face $\&$ for all greuance $\&$ apostemes $\&$ boches $\&$ a gayn $\mathrm{y}^{\mathrm{e}}$ kancer $\& \mathrm{y}^{\mathrm{e}}$ fester $\mathrm{y} a^{\mathrm{t}}$ commes in $\mathrm{y}^{\mathrm{e}}$ theis $\&$ legges $\&$ shennes $\&$ feete $\&$ for to staunchen a womans flowres.

156 after] aster 
The two vaynes vnder $y^{\mathrm{e}}$ inner ancles on ayther fote one serues for sande in $\mathrm{y}^{\mathrm{e}}$ bledder $\&$ for ye stonen $\&$ for women y $a^{\mathrm{t}}$ bene noght clene purged after child berynges $\&$ for women $y a^{t}$ may noght consayfe, and also for to make yane hafe yair floures when yai bene stopped.

The two vaynes vnder ye vtterer ancles on ayther fote one serues for greuance of the hanches $\& y^{\mathrm{e}}$ longes $\& \mathrm{y}^{\mathrm{e}}$ reynes $\&$ for swellynges $\&$ boches $\&$ apostemes $\&$ for $y^{\mathrm{e}}$ ballok

f. $61^{\mathrm{v}}$ stones $\&$ for lattyng off vryne $\&$ for $y^{\mathrm{e}}$ chaudpysse.

When any vayne shall blede on $y^{\mathrm{e}}$ fete, $\mathrm{y}^{\mathrm{e}}$ fote moie be sett in hote water.

Iff ony swone for bledynges \& it be wynter tyme, wessh his face with hote water $\&$ ye palmes of his handes \& ye soles off his feete.

And if it be somer tyme, wash hym with cald water $\&$ make hym brake $\&$ put to his nose yeyll pulioll \& mynte $\&$ horsement $\&$ spryng cold aysell or venegre on his nakyd side.

And if $y^{\mathrm{e}}$ place swelle y $a^{\mathrm{t}}$ bledys, take oyle $\&$ louke water in wynter $\&$ lay to ${ }^{t}{ }^{t} h$ a cloute. In somer bathen $\&$ froyte $y^{\mathrm{e}}$ soles of his fete with cold water.

And fro saynt Petres day in Feuerzer into ye vtaues day of ye assumpcion, vse the on ye left syde.

The vertues of blodelattynge. It kepys a mans mynde. It brynges it agayn. It clensys his bledder. It tempers his brayn. It hetys his marow. It coppyus his heringes.

$16761 \mathrm{v}$ ] venerabil; marginal note located in the header section of the page written in a different hand and different ink; also the word venerbil, blurred -intentional rubbing-off. 181 left ] lest. 


\section{GLOSSARY}

The glossary includes all the words contained in the edited text whose spellings and/or meanings differ in any aspect from PDE and may cause confusion in the interpretation of the text. The order is alphabetical. There is no conflation as regards alternative spellings. Thus, variants like $\langle j\rangle,\langle y\rangle,\langle i\rangle$, for instance, are entered as they appear in the MS. For ease of reference, I provide the line where an instance of each entry appears. For the glossary, I have mainly used for reference the MED and the OED, though some other sources have also been consulted, such as the editions by Mowat, Henslow, Ogden; and as the manuals by Hunt, Norri (Names of Sicknesses and Names of Body Parts).

The following abbreviations are used:

\begin{tabular}{llllll}
\hline adj. & adjective & e & early & ppl. & past participle \\
\hline adv. & adverb, adverbial & fem. & feminine & pron. & pronoun \\
\hline art. & article & gen. & genitive & prpl. & present participle \\
\hline aux. & auxiliary & imp. & imperative & prs. & present simple \\
\hline comp. & comparative & ind. & indicative & subj. & subjunctive \\
\hline conj. & conjunction & L & Latin & sg. & singular \\
\hline def. & definite & n. & noun & sup. & superlative \\
\hline dem. & demonstrative & pers. & person & v. & verb \\
\hline dvbln. & deverbal noun & pl. & plural & & \\
\hline
\end{tabular}

appostymes: $n$. pl. a gathering of purulent matter in any part of the body; a large deep-seated abscess \#37.

ayther: pron. either $\# 91$.

blodder: $n$. bladder $\# 100$.

blodymenyson: $n$. discharge from the bowels containing blood \#99.

boches: $n$. a hump, a swelling, a tumour \#37. cald: adj. cold \#171. cardiacles: $n$. $p l$. from L cardiaca; a malady characterized by pain in the heart and palpitation; also, a disease characterized by feebleness and profuse sweating; \#73.

chaudpysse: $n$. A urinary or venereal disease \#99.

cloute: $n$. a piece of cloth \#175. craluestelle: prob. the subclavian vein and artery \#116.

defautes: $n$. lack $\# 72$.

defouled: $n$. damage $\# 20$.

destres: $n$. pl. the right hand \#65.

dropcy: $n$. A morbid condition characterized by the accumulation of watery fluid in the serous cavities or the connective tissue of the body \#130.

een: $n$. s. eye \#41.

euyll(e): $n$. pain \#16.

Feuerzer: $n$. February \#178.

flebe: adj. feeble \#56.

fransye: $n$. insanity, delirium, madness, mental derangement \#19.

froyte: $v$. rub $\# 176$.

greuans: $n$. see greuaunce \#105. 
greuaunce: $n$. grievance $\# 72$.

hanches: $n$. $p l$. the part of the human body between the lowest ribs and the thighs, the hips, haunch \#115.

harmmes: $n$. pl. arms \#137.

hempp: $n$. the plant hemp \#119.

heued(e): $n$. head \#45.

jaundes: $n$. jaundice; A morbid condition caused by obstruction of the bile, and characterized by yellowness of the conjunctiva, skin, fluids, and tissues, and by constipation, loss of appetite, and weakness \#88.

leche: $n$. the bare skin? \#85.

leyh3ning: dvbln. haemorrhage?? \#134.

litarge: $n$. white or red lead $\# 16$.

medil: adj. middle \#71.

mekill: adj. much \#23.

meselry: $n$. leprosy or similar disfiguring disease \#21.

mete: $n$. food, meal $\# 11$.

mot: $v$. must \#38.

mygrayn: $n$. hemicrania \#14.

mylte: $n$. the spleen \#88.

or: $v .3$ pers. pl. are \#93.

pyntell: $n$. the penis \#129.

rewms: $n$. pl. Watery or mucous

secretions, esp. as collecting in or dripping from the eyes, nose, or mouth, originally believed to originate in the brain or head and to be capable of causing disease \#28. rottyng: $d v b l n$. putrefaction \#61.

schab: $n$. scab \#48.

sercle: $n$. anatomical feature of circular form; in this case the cubital area \#79.

squisies: $n$. pl. suppurative tonsillitis \#59. strayt -breth: adj. short of breath \#77. superflewites: $n$. $p l$. excessive growth \#35. swone: $v$. pres. subj. faint \#168.

thees: $n$. pl. thighs \#118.

thome: $n$. thumb $\# 90$.

tyngelyng: $d v b l n$. The ringing of the ears; a thrilling or unpleasant tickling of the ear \#33.

vayne: $n$. vein \#9.

vices: $n$. pl. a physical imperfection, a disorder \#54.

vtaues: $n$. $p l$. the eighth day following a feast day, counting the day itself, an octave \#179.

waxis: $v .3$ pers. $s$. to increase in size through natural growth, grow \#18. wlatynges: $d v b l n$. sickness of the stomach; nausea; vomiting \#87.

wodenes: $n$. unsoundness or derangement of mind, lunacy, mania, madness \#20. ylkan: pron. each one \#34. yorow: prep. through \#17.

\section{CODA}

This paper proposes an edition of a hitherto unedited fifteenth-century English text on phlebotomy. This text has never received scholarly attention, and there is, therefore, no information as to its language, dialectal provenance, or early history and affiliation. This article fills the gap and offers this information. The poor physical condition of the manuscript volume calls for an immediate action to preserve codicological and linguistic details. One important finding of this study concerns the sources of W, ff. $58 \mathrm{v}-61 \mathrm{v}$, which cannot be safely attributed to Isidore of Seville, as referenced in the original text. I have found, however, some evidence relating this text with the pseudo-Bedan De minutione sanguinis sive de phlebotomia, which, like our text, contains astrological information useful for bloodletting procedures. 
A study of the language of the text has been very helpful for the dialectal localization of the text of W, ff. $58 \mathrm{v}-61 \mathrm{v}$. For this purpose, a linguistic profile of the scribe has been done using a questionnaire to evince highly dialectal forms. Many of the variants obtained reveal the Northern stratum of this text, and I have suggested the region of Westmorland as a likely area of provenance. This information might be of use as an addition to the data for this county already given in the LALME in other new localizations of Middle English documents.

As pointed out in the introduction of this paper, editorial work here has greatly followed the tradition of mid-twentieth century editors of medieval texts. The purpose of doing this is to provide cultural, paleographic and linguistic evidence to understand and contextualize the text. Editions like the one presented here are also beneficial for students and for researchers, not exclusively in (historical) linguistics, but also in the history of sciences. If otherwise as it stands, a fresh and tailor-made version of this text can be produced after the edition presented here in order to be included in larger compilations of similar texts for computerized linguistic research.

Reviews sent to authors: 2 January 2020

Revised paper accepted for publication: 28 January 2020 


\section{WORKS CITED}

Alonso-Almeida, Francisco. "Punctuation Practice in a Late Medieval English Remedybook". Folia Linguistica Historica, 21.1-2 (2002): 207-232.

Alonso-Almeida, Francisco \& Ruth Carroll. "A New Proposal for the Classification of Middle English Medical Texts", Voices on the Past: Studies in Old and Middle English Language and Literature. Ed. Alicia Rodríguez-Álvarez \& Francisco Alonso Almeida. A Coruña: Netbiblo, 2004. 21-33.

Benskin, Michael \& Margaret Laing, "Translations and Mischsprachen in Middle English Manuscripts", So Meny People Longages and Tonges: Philological Essays in Scots and Mediaeval English Presented to Angus McIntosh. Ed. Michael Benskin and Michael Samuels. Edinburgh: Edinburgh UP, 1981. 55-106.

Codoñer, Carmen. "Textes médicaux insérés dans les Etymologiae isidoriennes", Cahiers de Recherches Médiévales .16 (2008):17-37.

Davis, Bonnie Karen. Phlebotomy: From Student to Professional. New York: Cengage Learning, 2011.

de la Cruz Cabanillas, Isabel: “Genre and Text-Type Conventions in Early Modern Women's Recipe Books”, Revista de Lingüistica y Lenguas Aplicadas 12 (2017): 13-21.

Giles, John Allen. The Complete Works of Venerable Bede: Scientific Tracts and Appendix, London: Whittaker and Co., 1843.

Henslow, George, ed. Medical Works of the Fourteenth Century Together with a List of Plants Recorded in Contemporary Writings, with Their Identifications. London: Chapman and Hall Ltd., 1899 [1972, reprint]).

Horobin, Simon \& Jeremy J. Sмiтh. An Introduction to Middle English. Oxford: Oxford UP, 2002.

Hunt, Tony \& Michael Benskin, eds. Three Receptaria from Medieval England: The Languages of Medicine in the Fourteenth Century, Medium Aevum Monographs, N.S., vol 2. Oxford: Oxford UP, 2001.

Jordan, Richard. Handbook of Middle English Grammar: Phonology, transl. and rev. by E. Crook. The Hague, 1974 [1925].

Kurath, Hans, ed. Middle English Dictionary. Ann Arbor, online edition: https://quod.lib. umich. $\mathrm{edu} / \mathrm{m} / \mathrm{middle-english-dictionary/dictionary.}$

Ogden, Margaret S., ed. The 'Liber de Diversis Medicinis' in the Thornton Manuscript (MS. Lincoln Cathedral A.5.2). London: EETS o.s. 207, 1938; revised edition 1969.

Oxford English Dictionary Online. September 2019. Oxford UP. https://www.oed.com.

McIntosh, Angus, M.L. Samuels, Michael Benskin, Margaret Laing and Keith Williamson. $A$ Linguistic Atlas of Late Mediaeval English, 4 vols, Aberdeen: Aberdeen UP, 1986.

Matheson, Lister, ed. Popular and Practical Science of Medieval England. Medieval Texts and Studies, 11. Michigan: Michigan State UP, 1994.

Mooney, Linne R. “Diet and Bloodletting: A Monthly Regimen”, Popular and Practical Science of Medieval England. Ed. Lister M Matheson. Michigan Michigan UP, 1994. 245-261.

Mowat, John Lancaster G., ed. Alphita. A Medico-Botanical Glossary from the Bodleian Manuscript, Selden B.35. Anecdota Oxoniensia, Mediaeval and Modern Series. Vol. 1, part 1. Oxford: Clarendon Press, 1887. 
Norri, Juhani. Names of Body Parts in English, 1400-1550. Annales Academiae Scientiarum Fennicae. vol. 291, Helsinki: Finnish Academy of Science and Letters, 1998.

Norri, Juhani. Names of Sicknesses in English, 1400-1550: An Exploration of the Lexical Field. Annales Academiae Scientiarum Fennicae Dissertationes Humanarum Litterarum, vol.63. Helsinki: Finnish Academy of Science and Letters, 1992.

Parapia, Liakat A. "History of Bloodletting by Phlebotomy." British Journal of Haematology, 143 (2008): 490-495.

Rodríguez Álvarez, Alicia. The Role of Punctuation in 15th-century Vernacular Deeds. Folia Linguistica Historica, 19. 1-2 (1998): 27-51.

Siraisi, Nancy G. Medieval and Renaissance Medicine. An Introduction to Knowledge and Practice, Chicago: The U of Chicago P, 1990.

Stell, Philip Michael. Medical Practice in Medieval York, New York: Borthwick Publications, 1996.

Taavitsainen, Irma, Peter Murray Jones, Päivi Pahta, Turo Hiltunen, Ville Marttila, Maura Annikki Ratia, Carla Suhr, \& Jukka Tyrkкö. "Medical texts in 1500-1700 and the corpus of the Early Modern English Texts", Medical Writing in Early Modern English. Ed. Irma Taavitsainen, \& Päivi Pahta, Cambridge: Cambridge UP. 2011. 9-29.

Voigts, Linda E. "Multitudes of Middle English Medical Manuscripts, or the Englishing of Science and Medicine", Manuscript Sources of Medieval Medicine. A Book of Essays. Ed. M. Schlesinger, New York and London: Routledge, 1995. 183-195.

Voigts, Linda E. and Michael McVaugh, eds. A Latin Technical Phlebotomy and its Middle English Translation, Transactions of the American Philological Society. 741984.

Wear, Andrew. Knowledge and Practice in English Medicine 1550-1680. Cambridge: Cambridge UP, 2000.

Wellcome Library. Digital collection: Medieval and Early Modern manuscripts. October, 2019. https://wellcomelibrary.org/collections/browse/collections/digwms. 
